\title{
The Impact of Indoleamine 2,3-dioxygenase (IDO) Expression on Stage III Gastric Cancer
}

\author{
MASAAKI NISHI, KOZO YOSHIKAWA, JUN HIGASHIJIMA, TAKUYA TOKUNAGA, \\ HIDEYA KASHIHARA, CHIE TAKASU, DAICHI ISHIKAWA, YUMA WADA and MITSUO SHIMADA \\ Department of Surgery, University of Tokushima Graduate School, Tokushima, Japan
}

\begin{abstract}
Background/Aim: Indoleamine 2,3-dioxygenase (IDO) down-regulates $T$ cell activation, attenuates regulatory $T$ cell (Treg) activation and is related to immune tolerance. The aim of the study was to clarify the significance of IDO expression and analyze the relationships between the expression of IDO, TGF- $\beta$, and Foxp3 in gastric cancer $(G C)$. Patients and Methods: A total of 60 patients who underwent curative gastrectomy for stage III gastric cancer were included in the study. The expression of IDO, TGF- $\beta$, and Foxp 3 was examined by immunohistochemistry and the relationship of each expression level to several prognostic factors was examined using univariate and multivariate analyses. Results: IDO expression was not positively correlated with any of the factors examined. IDO expression was positively correlated with TGF- $\beta$ expression $(p<0.05)$, and TGF- $\beta$ expression was positively correlated with FoxP 3 expression $(p<0.05)$. Overall survival $(O S)$ rates were significantly poorer in the IDO-positive group compared to the IDO-negative group (3-year OS, 78.5\% vs. 90\%, respectively; $p<0.05)$. Multivariate analysis confirmed IDO expression as independent prognostic factors in OS. Diseasefree survival (DFS) was significantly poorer in the IDOpositive group compared to the IDO-negative group (3-year DFS, $59.3 \%$ vs. $69.3 \%$, respectively; $p<0.05)$. Conclusion: IDO is associated with poor prognosis and immuno-tolerance through attenuation of Treg activation in Stage III GC.
\end{abstract}

Recent refinements in the investigation of tumor microenvironments have advanced cancer treatments dramatically. For example, regulating immune tolerance is key for controlling malignancy $(1,2)$ and involves the 'don't

Correspondence to: Masaaki Nishi, MD, Ph.D., F.A.C.S, Department of Surgery Tokushima University, 3-18-15 Kuramotocho, Tokushima, 770-8503 Japan. Tel: +81 886337137, Fax: +81 886319698,e-mail: nishi.masaaki@ tokushima-u.ac.jp

Key Words: Gastric cancer, indoleamine 2,3-dioxygenase, regulatory $\mathrm{T}$ cells. kill me' signal, $\mathrm{T}$ cell dysfunction, the programmed cell death protein 1 (PD-1) - programmed cell death ligand 1 (PD-L1) pathway, intra-tumoral neutrophils, monocytes, and regulatory $\mathrm{T}$ cells (Tregs).

Indoleamine 2,3-dioxygenase (IDO) is a heme-containing intracellular enzyme that catalyzes the formation of tryptophan into kynurenine. The role of IDO in inhibiting the immune response was first described in studies of fetal rejection (3). IDO performs immunoregulatory roles in tumor microenvironments and is expressed in dendritic cells (DCs), cancer cells, and macrophages. IDO attenuates Treg activation and induces immune-tolerance. We previously reported that IDO-positive DCs induce Foxp $3^{+}$Tregs in the tumor microenvironment of intraductal papillary mucinous neoplasms of the pancreas (4), and it was recently suggested that IDO expressed in tumor cells correlates with poor prognosis $(5,6)$. However, little is known regarding the significance of the relationship between IDO expression and gastric cancer (GC).

The aim of this study was to clarify the significance of IDO expression and to analyze the relationships between IDO, TGF- $\beta$, and Foxp3 expression in patients with gastric cancer.

\section{Patients and Methods}

Patients. A total of 60 patients (44 men and 16 women; mean age: 67.8 years; range $=38-80$ years) who had undergone curative surgical resection for Stage III gastric cancer at Tokushima University Hospital between 2006 and 2012 were included in this study. Twenty-six patients $(37.1 \%)$ underwent total gastrectomy and 34 $(62.9 \%)$ underwent distal gastrectomy. The mean follow-up period was 41 months (range $=12-87$ months). All patients underwent S-1 based adjuvant chemotherapy. Factors were defined according to the 14th edition of the Japanese Classification of Gastric Carcinoma (7). This study was authorized in advance by the Institutional Review Board of The University of Tokushima Graduate School of Medical Science, and all patients provided written informed consent (No.2901). These patients were also included in our previous study (8).

Immunohistochemistry. The immunohistochemistry method used was previously reported (8). Tissue samples were formalin-fixed and 
paraffin-embedded. Serial sections were cut at $5 \mu \mathrm{m}$ intervals, dewaxed, deparaffinized in xylene, and rehydrated through a series of graded alcohols. Samples were boiled for $20 \mathrm{~min}$ in a microwave oven in citrate buffer ( $\mathrm{pH}$ 6.0) for antigen retrieval. Endogenous peroxidases were blocked with $0.3 \%$ hydrogen peroxidase for 30 min, followed by incubation in 5\% goat serum for $60 \mathrm{~min}$ to prevent nonspecific antigen binding. The slides were then incubated with primary antibodies overnight at $4{ }^{\circ} \mathrm{C}$. The following primary antibodies and dilutions were used: mouse monoclonal antibody for IDO (1:40; R\&D Systems, AF1086, Minneapolis, MN, USA), mouse monoclonal antibody for TGF- $\beta$ (1:100; Abcam, ab20034), and mouse monoclonal antibody for Foxp3 (1:100; Abcam, ab20034). Secondary antibody binding was detected by using an Envision Dual link system-HRP (DAKO). A secondary peroxidaselabelled polymer conjugated to goat anti-mouse immunoglobulins was applied for $60 \mathrm{~min}$. The sections were developed in 3,3diaminobenzidine and counterstained with Mayer's haematoxylin. Each slide was dehydrated through graded alcohols and covered with a coverslip. The presence of positive cells on each slide was determined by a pathologist in a blinded manner. IDO expression was predominantly located in the cytoplasm at the invasive front of the tumour. Staining intensity was graded as: $0=$ no staining, $1+=$ weak staining, $2+=$ moderate staining and $3+=$ strong staining. The proportion scores were: 0 , none; $1,<10 \% ; 2,10-50 \% ; 3,51$ $80 \% ; 4,>80 \%$. A total score of greater than $4+$ was defined as IDOpositive expression (Figure 1B). Twenty-two patients (38.3\%) were IDO-positive. TGF- $\beta$ positivity was recorded by counting stained cells in tumor tissue $\geq 10 \%$ at $200 \times \operatorname{HPF}(8)$. Thirty patients $(50.0 \%)$ were TGF- $\beta$ positive. Immunohistochemistry to quantify FoxP 3 was performed as in our previously study (8). Foxp3-positivity was recorded by counting 10 or more Foxp3-stained $\mathrm{T}$ cells in each cancer tissue section at $200 \times$ HPF. Eighteen patients (17.6\%) were Foxp3-positive.

Ethical statement. All procedures followed were in accordance with the ethical standards of the responsible committee on human experimentation (institutional and national) and with the Helsinki Declaration of 1964 and later versions. Informed consent or a substitute was obtained from all patients included in the study.

Statistical analysis. All statistical analyses were performed using JMP 8.0.1 statistical software (SAS, Cary, NC, USA). Continuous variables were compared using Mann-Whitney $U$-tests, and categorical data were tested using $\chi^{2}$ tests. Survival curves were calculated by the Kaplan-Meier method and compared using logrank tests. The prognostic potentials of the parameters were analyzed by univariate analysis. Relative risk and $95 \%$ confidence intervals (CI) were estimated using the Cox proportional hazard model with stepwise forward selection. Statistical significance was defined as $p<0.05$.

\section{Results}

The characteristics of the IDO-positive and -negative groups are shown in Table I. In terms of clinicopathological variables, IDO expression was not positively correlated with any clinicopathological factor investigated.

Overall survival (OS) rates were significantly poorer in the IDO-positive group compared with the IDO-negative
Table I. Characteristics of IDO-positive and IDO-negative patients.

\begin{tabular}{lccc}
\hline Variables & $\begin{array}{c}\text { Positive } \\
(\mathrm{n}=23)\end{array}$ & $\begin{array}{c}\text { Negative } \\
(\mathrm{n}=37)\end{array}$ & $p$-Value \\
\hline Age & $70 \pm 10$ & $67 \pm 13$ & 0.68 \\
Gender $(\mathrm{M} / \mathrm{F})$ & $19 / 4$ & $27 / 10$ & 0.39 \\
Dif/Undif & $12 / 11$ & $16 / 21$ & 0.46 \\
$\mathrm{~T} 2,3 / 4$ & $13 / 10$ & $23 / 14$ & 0.30 \\
$\mathrm{~N}(\leq 5 / 6 \leq)$ & $10 / 13$ & $24 / 13$ & 0.38 \\
Type & $2 / 3 / 16 / 2$ & $3 / 6 / 25 / 3$ & 0.99 \\
Location $(\mathrm{U} / \mathrm{M} / \mathrm{L})$ & $2 / 12 / 9$ & $7 / 17 / 13$ & 0.56 \\
Tumor size $(<5 / 5 \mathrm{~cm} \leq)$ & $6 / 17$ & $14 / 23$ & 0.35 \\
CEA $(<5 / 5 \mathrm{ng} / \mathrm{ml} \leq)$ & $18 / 5$ & $31 / 6$ & 0.59 \\
CA19-9 $(<37 \mathrm{IU} / \mathrm{ml} \leq)$ & $14 / 9$ & $28 / 9$ & 0.22 \\
DG/TG & $8 / 15$ & $18 / 19$ & 0.29 \\
Operative time & $311 \pm 70$ & $294 \pm 158$ & 0.34 \\
\hline
\end{tabular}

group (3-year OS, $78.5 \%$ vs. 90\%, respectively; $p<0.05$ ) (Figure 2A). Univariate analysis identified the number of positive lymph node metastases and IDO expression as significant prognostic factors for OS $(p<0.05)$. Multivariate analysis confirmed $\mathrm{T}$ factor levels, the number of positive lymph node metastases, and IDO expression as independent prognostic factors (relative risks 3.63, 14.2, and 2.75, respectively) (Table II).

Disease-free survival (DFS) was significantly poorer in the IDO-positive group compared with the IDO-negative group (3-year DFS, 59.3\% vs. 69.3\%, respectively; $p<0.05$ ) (Figure 2B). Univariate analysis identified that the number of positive lymph node metastases and IDO expression are significant prognostic factors for DFS $(p<0.05)$. Multivariate analysis confirmed that $\mathrm{T}$ factor levels and the number of positive lymph node metastases are independent risk factors for recurrence $(p<0.05)$. IDO expression tended to be an independent recurrent factor $(p<0.1)$ (Table III).

IDO expression was positively correlated with TGF- $\beta$ expression $(p<0.05)$ and TGF- $\beta$ expression was positively correlated with FoxP3 expression $(p<0.05)$ (Figure 3$)$.

\section{Discussion}

The results of this study demonstrated that IDO expression is a marker for poor prognosis both in terms of OS and DFS, IDO expression correlated with TGF- $\beta$ expression, and TGF$\beta$ expression correlated with Foxp3 expression in patients with stage III gastric cancer after curative resection. This is the first report to clarify the relationships between IDO, TGF- $\beta$, and Foxp 3 expression in gastric cancer after curative resection.

IDO comprises two subtypes: IDO1 and IDO2. IDO1 plays an immune-regulatory role. In this article, IDO refers to IDO1. IDO was first described in studies of acquired tolerance, fetus 


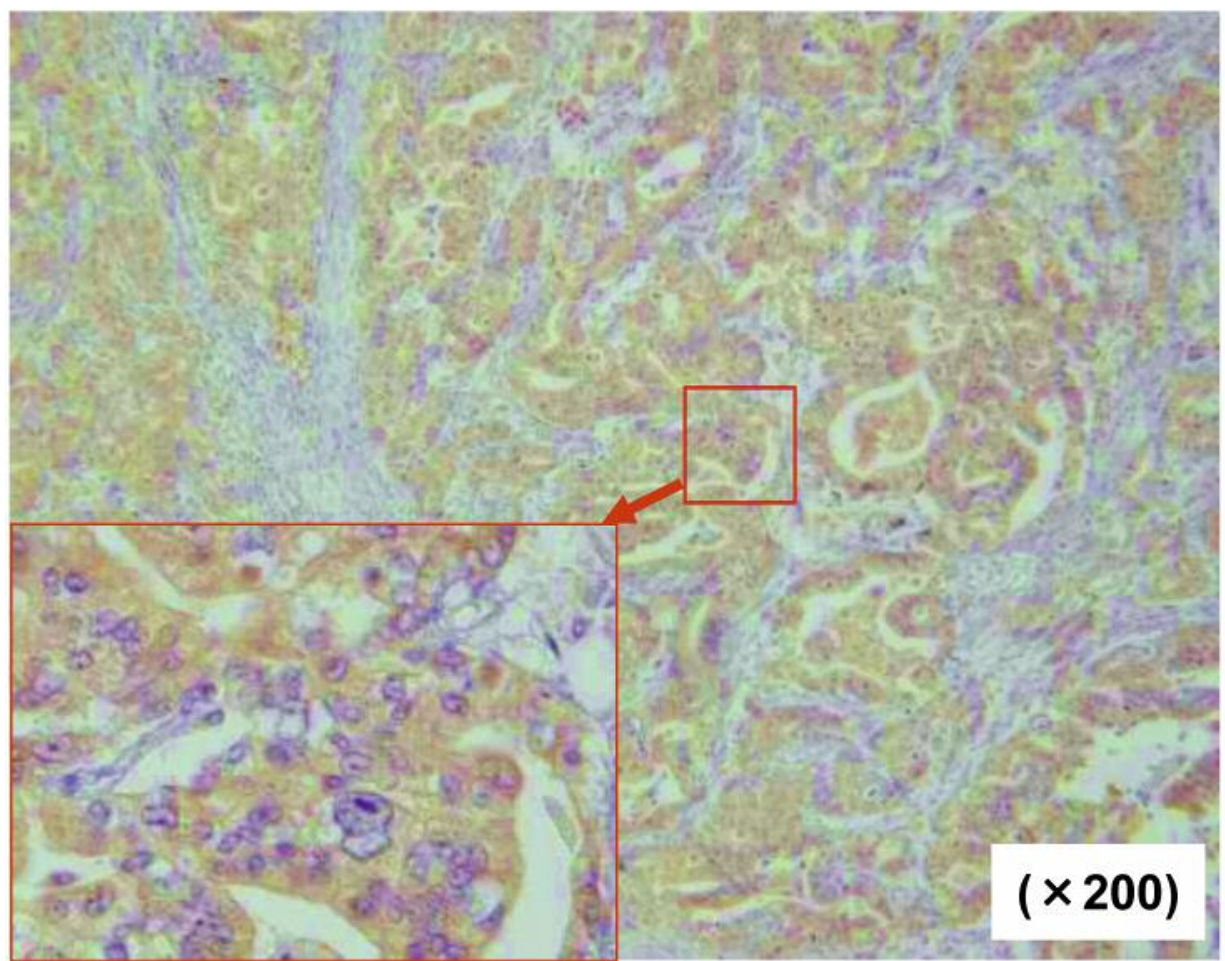

Figure 1. Immunohistochemistry. A: IDO-positive expression in cancer tissue. B: IDO-negative expression in cancer tissue.

a

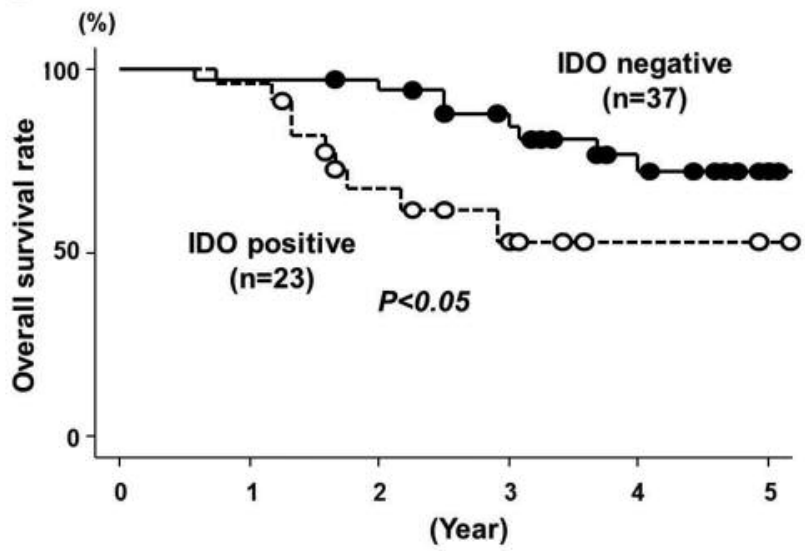

Figure 2. Kaplan-Meier analysis of $O S$ and DFS for IDO $(A, B)$.

allogenic pregnancy, and mucosal tolerance to apoptotic cells (3, 9-11). IDO plays important roles in regulating and maintaining the immune system through $\mathrm{T}$ cell activation, and in aiding the tolerance in the tumor microenvironment. The mechanism underlying the action of IDO involves activation of GCN2. GCN has an inhibitory effect on T cell proliferation and promotes Treg differentiation and stimulates tumor b

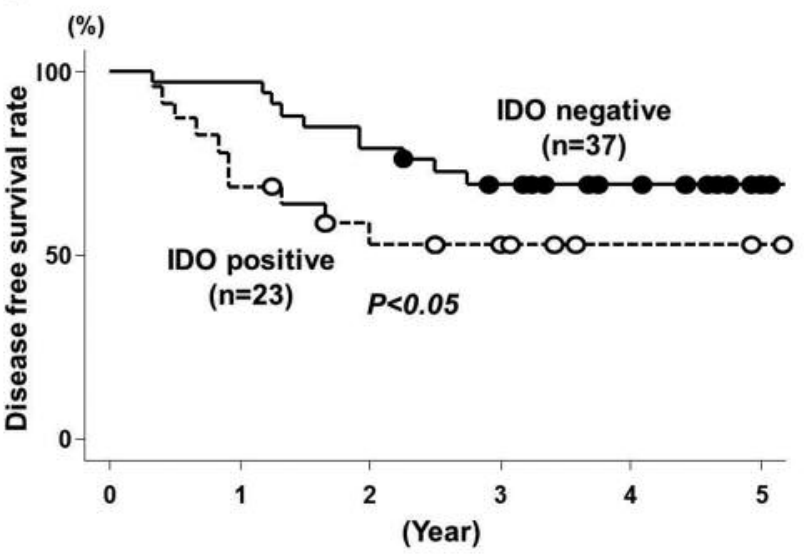

immune-inhibitory cytokines such as IL10 and TGF- $\beta$ (12-15). Furthermore, IDO changes the phenotype of DCs and macrophages to an immunosuppressive form (16).

Only one study has examined IDO expression in gastric cancer (17). Liu et al. reported that positive IDO expression correlated with poor prognosis, although the precise mechanism remains unclear. The roles of IDO and its 

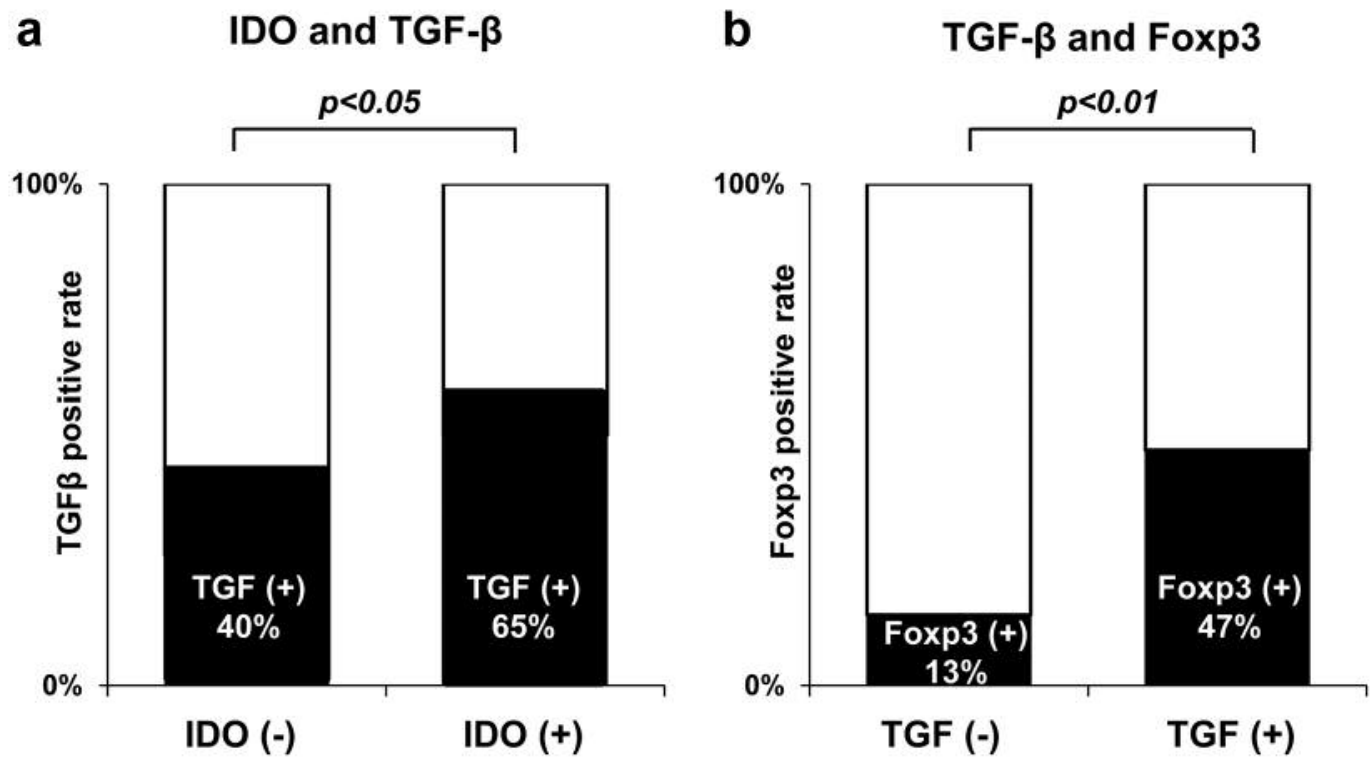

Figure 3. Correlation among IDO and TGF, FoxP3 $(A, B)$.

Table II. Univariate and multivariate analysis for OS $(n=60)$.

\begin{tabular}{|c|c|c|c|c|}
\hline \multirow[t]{2}{*}{ Variables } & \multicolumn{2}{|c|}{ Univariate } & \multicolumn{2}{|c|}{ Multivariate } \\
\hline & $\begin{array}{c}3 \text {-years OS } \\
\text { rate }(\%)\end{array}$ & $p$-Value & HR $(95 \% \mathrm{CI}) \quad p$ & $p$-Value \\
\hline Age $(<70 / 70 \leq)$ & $82.0 / 64.5$ & 0.20 & & \\
\hline Gender (M/F) & $66.3 / 92.3$ & 0.12 & & \\
\hline Dif/Undif & $64.8 / 75.0$ & 0.57 & & \\
\hline Т $2,3 / 4$ & $80.6 / 61.0$ & 0.07 & $3.63(1.34-10.0)$ & $<0.05$ \\
\hline$N(\leq 5 / 6 \leq)$ & $91.8 / 44.4$ & $<0.01$ & $14.2(1.85-11.1)$ & $<0.05$ \\
\hline Tumor size $(<5 / 5 \mathrm{~cm} \leq)$ & $71.1 / 70.5$ & 0.84 & & \\
\hline DG/TG & $89.8 / 82.0$ & 0.94 & & \\
\hline IDO $(-) /(+)$ & $90.0 / 78.5$ & $<0.05$ & $2.75(1.01-7.58)$ & $<0.05$ \\
\hline FoxP3 $(-) /(+)$ & $89.3 / 85.0$ & 0.98 & & \\
\hline TGF $\beta(-) /(+)$ & $92.4 / 74.0$ & 0.25 & & \\
\hline
\end{tabular}

\begin{tabular}{|c|c|c|c|c|}
\hline \multirow[t]{2}{*}{ Variables } & \multicolumn{2}{|c|}{ Univariate } & \multicolumn{2}{|c|}{ Multivariate } \\
\hline & $\begin{array}{c}\text { 3-years OS } \\
\text { rate }(\%)\end{array}$ & $p$-Value & $\mathrm{HR}(95 \% \mathrm{CI}) \quad l$ & $p$-Value \\
\hline Age $(<70 / 70 \leq)$ & $70.3 / 56.4$ & 0.41 & & \\
\hline Gender $(\mathrm{M} / \mathrm{F})$ & $58.0 / 77.4$ & 0.18 & & \\
\hline Dif/Undif & $59.1 / 65.4$ & 0.52 & & \\
\hline Т $2,3 / 4$ & $71.6 / 49.1$ & 0.08 & $2.77(1.13-6.82)$ & $<0.05$ \\
\hline$N(\leq 5 / 6 \leq)$ & $81.6 / 41.0$ & $<0.01$ & $19.6(2.62-14.3)$ & $<0.05$ \\
\hline Tumor size $(<5 / 5 \mathrm{~cm} \leq)$ & $65.8 / 56.8$ & 0.86 & & \\
\hline DG/TG & $55.1 / 68.9$ & 0.24 & & \\
\hline IDO $(-) /(+)$ & $69.3 / 59.1$ & $<0.05$ & $2.17(0.88-5.35)$ & 0.09 \\
\hline FoxP3 $(-) /(+)$ & $63.1 / 60.9$ & 0.98 & & \\
\hline $\operatorname{TGF} \beta(-) /(+)$ & $65.9 / 60.0$ & 0.25 & & \\
\hline
\end{tabular}

correlation with other molecules such as TGF- $\beta$ and FoxP3 were not investigated previously. Our present study shows that IDO is positively correlated with the expression of TGF$\beta$. This is in accordance with TGF- $\beta$ correlating with the expression of transcription factor Foxp3, widely known to be involved in the development and function of Tregs (18).

The survival curve of IDO-positive patients in this study was similar to that of surgery-alone patients in the ACTSGC trial (19), and IDO-positive patients had poor prognosis in both OS and DFS. The recruitment of immune cells (neutrophils, cytotoxic T cells) and exhaustion of Tregs are crucial for the sensitivity of the tumor towards chemotherapy (20). IDO expression may induce chemo-resistance.

IDO up-regulates PD-1 and PTEN expression (21). We previously reported PD-1 expression in gastric cancer patients and that PD-1 expression correlated with poor prognosis in gastric cancer after curative resection (8). The correlation between IDO and PD-1, and IDO and PD-L1, was investigated in the present study but no significant correlations were observed (data not shown). 
Immunogenic agents targeting $\mathrm{T}$ cell immune checkpoints, such as PD-1, PD-L1, and cytotoxic T lymphocyteassociated antigen- 4 are currently being applied to the treatment of several types of cancers $(2,22,23)$. Regarding the targeting of IDO, IDO inhibitors such as indoximod (1-methyl-D-tryptophan) and epacadostat, combined with chemotherapy, vaccines, or checkpoint inhibitors, are currently undergoing clinical trials $(24,25)$. The present study confirmed IDO expression as a predictive factor after curative gastrectomy. Immunotherapy targeting of IDO may, thus, provide useful adjuvant treatment for patients with gastric cancer. Furthermore, IDO expression, used as a biomarker, can be estimated from the levels of tryptophan and kynurenine measured using liquid biopsy samples (26) and aids prediction of recurrence and prognosis.

In conclusion, IDO expression was associated with poor prognosis in patients with gastric cancer. IDO expression may, thus, represent a useful new therapeutic target for the treatment of gastric cancer.

\section{Conflicts of Interest}

The Authors declare that they have no conflict of interest.

\section{References}

1 Ishida Y, Agata Y, Shibahara K and Honjo T: Induced expression of PD-1, a novel member of the immunoglobulin gene superfamily, upon programmed cell death. EMBO J 11(11): 3887-3895, 1992.

2 Topalian SL, Hodi FS, Brahmer JR, Gettinger SN, Smith DC, McDermott DF, Powderly JD, Carvajal RD, Sosman JA, Atkins MB, Leming PD, Spigel DR, Antonia SJ, Horn L, Drake CG, Pardoll DM, Chen L, Sharfman WH, Anders RA, Taube JM McMiller TL, Xu H, Korman AJ, Jure-Kunkel M, Agrawal S, McDonald D, Kollia GD, Gupta A, Wigginton JM and Sznol M: Safety, activity, and immune correlates of anti-PD-1 antibody in cancer. N Engl J Med 366: 2443-2454, 2012.

3 Munn DH, Zhou M, Attwood JT, Bondarev I, Conway SJ, Marshall B, Brown C and Mellor AL: Prevention of allogeneic fetal rejection by tryptophan catabolism. Science 281(5380): 1191-1193, 1998.

4 Ikemoto T,Shimada M, Komatsu M, Yamada S, Saito Y, Mori H, Morine $\mathrm{Y}$, Imura S, Bando $\mathrm{Y}$ and Utsunomiya T: Indoleamine 2,3-dioxygenase affects the aggressiveness of intraductal papillary mucinous neoplasms through Foxp3+CD4+CD25+ T cells in peripheral blood. Pancreas 42(1): 130-134, 2013.

5 Ferdinande L, Decaestecker C, Verset L, Mathieu A, Moles Lopez X, Negulescu AM, Van Maerken T, Salmon I, Cuvelier $\mathrm{CA}$ and Demetter P: Clinicopathological significance of indoleamine 2,3-dioxygenase 1 expression in colorectal cancer. Br J Cancer 106: 141-147, 2019.

6 Maleki Vareki S, Rytelewski M, Figueredo R, Chen D, Ferguson PJ, Vincent M, Min W, Zheng X and Koropatnick J: Indoleamine 2,3-dioxygenase mediates immune-independent human tumor cell resistance to olaparib, gamma radiation, and cisplatin. Oncotarget 5: 2778-2791, 2014.
7 Japanese classification of gastric carcinoma: 3rd English edition. Gastric Cancer 101-112, 2011.

8 Eto S, Yoshikawa K, Nishi M, Higashijima J, Tokunaga T, Nakao T, Kashihara H, Takasu C, Iwata T and Shimada M: Programmed cell death protein 1 expression is an independent prognostic factor in gastric cancer after curative resection. Gastric Cancer 2: 466-471, 2016.

9 Matteoli G, Mazzini E, Iliev ID, Mileti E, Fallarino F, Puccetti P, Chieppa M and Rescigno M: Gut CD103+ dendritic cells express indoleamine 2,3-dioxygenase which influences $\mathrm{T}$ regulatory/T effector cell balance and oral tolerance induction. Gut 59(5): 595-604, 2010.

10 Sucher R, Fischler K, Oberhuber R, Kronberger I, Margreiter C, Ollinger R, Schneeberger S, Fuchs D, Werner ER, Watschinger K, Zelger B, Tellides G, Pilat N, Pratschke J, Margreiter R, Wekerle $\mathrm{T}$ and Brandacher G: IDO and regulatory T cell support are critical for cytotoxic T lymphocyte-associated Ag-4 Igmediated long-term solid organ allograft survival. J Immunol 188(1): 37-46, 2012.

11 Grohmann U, Orabona C, Fallarino F, Vacca C, Calcinaro F, Falorni A, Candeloro P, Belladonna ML, Bianchi R, Fioretti MC and Puccetti P: CTLA-4-Ig regulates tryptophan catabolism in vivo. Nat Immunol 3(11): 1097-1101, 2002.

12 Munn DH, Sharma MD, Baban B, Harding HP, Zhang Y, Ron D and Mellor AL: GCN2 kinase in T cells mediates proliferative arrest and anergy induction in response to indoleamine 2,3dioxygenase. Immunity 22(5): 633-642, 2005.

13 Fallarino F, Grohmann U, You S, McGrath BC, Cavener DR, Vacca C, Orabona C, Bianchi R, Belladonna ML, Volpi C, Santamaria P, Fioretti MC and Puccetti P: The combined effects of tryptophan starvation and tryptophan catabolites down-regulate $\mathrm{T}$ cell receptor zeta-chain and induce a regulatory phenotype in naive $\mathrm{T}$ cells. J Immunol 176(11): 6752-6761, 2006.

14 Mezrich JD, Fechner JH, Zhang X, Johnson BP, Burlingham WJ and Bradfield CA: An interaction between kynurenine and the aryl hydrocarbon receptor can generate regulatory $\mathrm{T}$ cells. $\mathrm{J}$ Immunol 185(6): 3190-3198, 2010.

15 Jaronen $M$ and Quintana FJ: Immunological relevance of the coevolution of IDO1 and AHR. Front Immunol 5: 521, 2014.

16 Manlapat AK, Kahler DJ, Chandler PR, Munn DH and Mellor AL: Cell-autonomous control of interferon type I expression by indoleamine 2,3-dioxygenase in regulatory CD19+ dendritic cells. Eur J Immunol 37(4): 1064-1071, 2007.

17 Liu H, Shen Z, Wang Z, Wang X, Zhang H, Qin J, Qin X, Xu J and Sun Y: Increased expression of IDO associates with poor postoperative clinical outcome of patients with gastric adenocarcinoma. Sci Rep 6: 21319, 2016.

18 Douglass S, Ali S, Meeson AP, Browell D and Kirby JA: The role of FOXP3 in the development and metastatic spread of breast cancer. Cancer Metastasis Rev 31(3-4): 843-854, 2012.

19 Sasako M, Sakuramoto S, Katai H, Kinoshita T, Furukawa H, Yamaguchi T, Nashimoto A, Fujii M, Nakajima T and Ohashi Y: Five-year outcomes of a randomized phase III trial comparing adjuvant chemotherapy with $\mathrm{S}-1$ versus surgery alone in stage II or III gastric cancer. J Clin Oncol 29(33): 4387-4393, 2011.

20 Pfirschke C, Engblom C, Rickelt S, Cortez-Retamozo V, Garris C, Pucci F, Yamazaki T, Poirier-Colame V, Newton A, Redouane Y, Lin YJ, Wojtkiewicz G, Iwamoto Y, Mino-Kenudson M, 
Huynh TG, Hynes RO, Freeman GJ, Kroemer G, Zitvogel L, Weissleder $\mathrm{R}$ and Pittet MJ: Immunogenic chemotherapy sensitizes tumors to checkpoint blockade therapy. Immunity 44(2): 343-354, 2016.

21 Sharma MD, Shinde R, McGaha TL, Huang L, Holmgaard RB, Wolchok JD, Mautino MR, Celis E, Sharpe AH, Francisco LM, Powell JD, Yagita H, Mellor AL, Blazar BR and Munn DH: The PTEN pathway in Tregs is a critical driver of the suppressive tumor microenvironment. Sci Adv 1(10): e1500845, 2015.

22 Schlößer HA, Drebber U, Kloth M, Thelen M, Rothschild SI, Haase S, Garcia-Marquez M, Wennhold K, Berlth F, Urbanski A, Alakus H, Schauss A, Shimabukuro-Vornhagen A, Theurich S, Warnecke-Ebertz U, Stippel DL, Zippelius A, Büttner R, Hallek M, Hölscher AH, Zander T, Mönig SP and von BergweltBaildon M: Immune checkpoints programmed death 1 ligand 1 and cytotoxic $\mathrm{T}$ lymphocyte associated molecule 4 in gastric adenocarcinoma. Oncoimmunology 5(5): e1100789, 2015.

23 Gibney GT, Weiner LM and Atkins MB: Predictive biomarkers for checkpoint inhibitor-based immunotherapy. Lancet Oncol 17(12): e542-e51, 2016.
24 Soliman HH, Minton SE, Han HS, Ismail-Khan R, Neuger A, Khambati F, Noyes D, Lush R, Chiappori AA, Roberts JD, Link C, Vahanian NN, Mautino M, Streicher H, Sullivan DM and Antonia SJ: A phase I study of indoximod in patients with advanced malignancies. Oncotarget 7(16): 22928-22938, 2016.

25 Spranger S, Koblish HK, Horton B, Scherle PA, Newton R and Gajewski TF: Mechanism of tumor rejection with doublets of CTLA-4, PD-1/PD-L1, or IDO blockade involves restored IL-2 production and proliferation of CD8(+) T cells directly within the tumor microenvironment. J Immunother Cancer 2: 3, 2014.

26 Suzuki Y, Suda T, Asada K, Miwa S, Suzuki M, Fujie M, Furuhashi K, Nakamura Y, Inui N, Shirai T, Hayakawa H, Nakamura $\mathrm{H}$ and Chida $\mathrm{K}$ : Serum indoleamine 2,3-dioxygenase activity predicts prognosis of pulmonary tuberculosis. Clin Vaccine Immunol 19(3): 436-442, 2012.

Received April 9, 2018

Revised May 7, 2018

Accepted May 8, 2018 